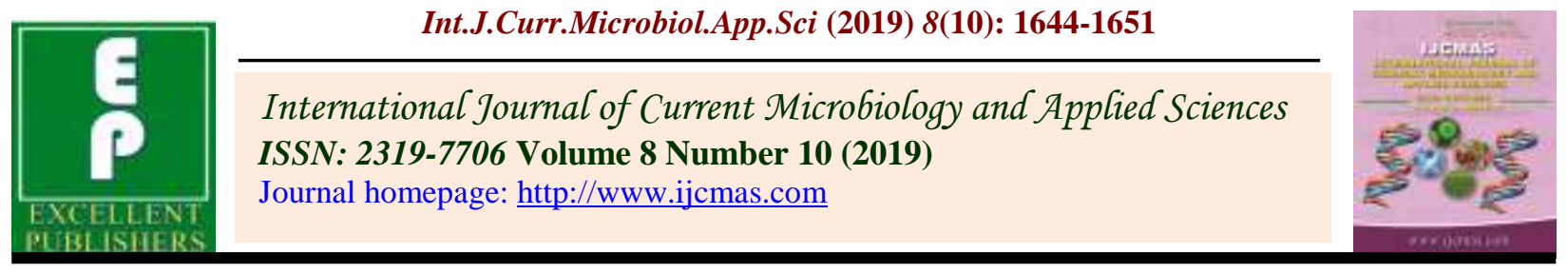

Original Research Article

https://doi.org/10.20546/ijcmas.2019.810.191

\title{
Response of Irrigation Scheduling on Yield Attributes, Productivity and Economics of Pigeonpea (Cajanus cajan L.)
}

\author{
G. V. Ghuge, K. T. Jadhav and A. S. Chavan*
}

COA, Badnapur, Vasantrao naik Marathwada Krishi Vidyapeeth, Parbhani (MS), India

*Corresponding author

\section{A B S T R A C T}

Keywords

Varieties, Irrigation,

Pigeonpea

Article Info

Accepted:

12 September 2019

Available Online:

10 October 2019

A field experiment was conducted at College of Agriculture, Badnapur on a clayey soil during kharif season of 2017 to find out the effect of with two factors viz., Varieties (three levels: $\mathrm{V}_{1^{-}}$BDN-711, $\mathrm{V}_{2^{-}}$BSMR-736, $\mathrm{V}_{3^{-}}$BDN-716) and four irrigation levels Rainfed (Control) $\left(\mathrm{I}_{1}\right)$, Bud initiation $\left(\mathrm{I}_{2}\right)$, Pod development $\left(\mathrm{I}_{3}\right)$, Bud initiation and Pod development $\left(\mathrm{I}_{4}\right)$ with 12 treatments combinations. Each experimental unit was repeated three times. The fertilizer dose of 25:50:00NPKkg $\mathrm{ha}^{-1}$ was applied after sowing. Amongst varieties, BDN-716 recorded maximum seed yield $\left(1697 \mathrm{~kg} \mathrm{ha}^{-1}\right)$ and net monitory returns $\left(51457 \mathrm{~kg} \mathrm{ha}^{-1}\right)$ than BSMR736, however, it was comparable with BDN-711 for seed yield. Amongst irrigation stages, two irrigations at bud initiation + pod development recorded significantly maximum seed yield $\left(2076 \mathrm{~kg} \mathrm{ha}^{-1}\right)$ and NMR (93435 Rs ha-1) followed by irrigation at pod development, irrigation at bud initiation and rainfed treatment, respectively. Highest water use efficiency was observed under irrigation at pod development $\left(29.18 \mathrm{~kg} \mathrm{ha}^{-1} \mathrm{~mm}^{-1}\right)$ followed by irrigation at bud initiation $\left(24.23 \mathrm{~kg} \mathrm{ha}^{-1} \mathrm{~mm}^{-1}\right)$ and two irrigations at bud initiation + pod development $\left(17.30 \mathrm{~kg} \mathrm{ha}^{-1} \mathrm{~mm}^{-1}\right)$.

\section{Introduction}

Pigeon pea is popular food in developing tropical countries. The green seeds serve as vegetable and ripe seeds are a source of flour, split seed $(d a l)$ used in soups or eaten with Rice, Wheat or Jawar roti. Dal contains as much as $22 \%$ protein, depending on cultivar and location. Tender leaves are used as a pot herb. Plants produce forage quickly and can be used as a perennial forage crop particularly for goats or used for green manure, often grown as a shade crop for tree crops or vanilla, a cover crop, or occasionally as a windbreak hedge. In Thailand and North Bengal, pigeon pea serves as host for the scale insect.

Limited and scanty rainfall in the rain fed areas makes pigeonpea vulnerable to experience moisture stress conditions during 
the later part of its growth, resulting in severe yield reduction. Sufficient soil moisture is the key to successful crop production in dryland areas.

Annual rainfall in several parts of dry lands is sufficient for one or more crops per year. Erratic and high intensity storms lead to runoff and erosion. The effective rainfall may be 65 per cent or sometimes less than 50 per cent. Hence, soil management practices have to be tailored to store and conserve as much rainfall as possible by reducing the runoff and increasing storage capacity of soil profile. The simple in situ moisture conservation technology developed to prevent or reduce water loss and to increase water intake is the Broad Bed and Furrow (BBF) method. This method is effective on black soils. It plays an important role in reducing the velocity when runoff occurs and increases the infiltration opportunity time and excess water is removed in large number of small furrows. Crops are sown on broad beds. In dryland farming areas of Northern Transition Zone of Karnataka, the rainfall is not only scanty but also erratic. Thus, soil moisture becomes the most limiting factor in production of pigeonpea.

In general surface irrigation methods viz., furrow irrigation and controlled flooding i.e. ridges and furrow are the most common methods of water delivery to pigeon pea. In these methods, appreciable quantity of irrigation water is lost due to conveyance, evaporation and percolation besides low application and distribution irrigation efficiencies compared to drip irrigation. However, for protective irrigation till now these methods are used and have better suitability in Marathwada region.

The effect of irrigation at different physiological growth stages like branching (B), flowering (F) and pod formation (P) stages and their different combinations on the yield components and yield of pigeon pea has proved beneficial in pigeonpea. Yield and yield components were significantly influenced by the application of irrigation. Three irrigations applied one each at branching, flowering and pod formation stages produced the highest seed yield, but it was at par with two irrigations applied at branching and flowering stages during all the three years. Irrigation at branching and flowering was found essential for higher seed production in pigeon pea grown during winter months. Single irrigation at flowering stage produced maximum seed yield. The increase in seed yield over control (rainfed) was $772 \mathrm{~kg} \mathrm{ha}^{-1}$ with irrigation at $\mathrm{B}$ (branching)+ $\mathrm{F}$ (flowering)+ $\mathrm{P}$ (pod formation), $703 \mathrm{Kg} \mathrm{ha}^{-1}$ at B (branching)+ F (flowering) and $548 \mathrm{Kg} \mathrm{ha}{ }^{-1}$ at flowering stages, respectively (Basu et al., 2009).

\section{Materials and Methods}

A field experiment was conducted during the period of 2017-18 at Experimental Farm of Agronomy at College of Agriculture Badnapur situated at $19^{\circ} 52^{\prime} 00^{\prime \prime}$ "North latitude and $75^{\circ}$ 44'00' East longitudes at $498 \mathrm{~m}$ altitude above mean sea level on clayey in texture, moderate in available nitrogen (160 kg ha $\left.{ }^{-1}\right)$, low in available phosphorus (10 kg ha-1), high in available potassium $\left(621 \mathrm{~kg} \mathrm{ha}^{-1}\right)$. The soil was moderately alkaline in reaction $(8.13 \mathrm{pH})$. In general, weather conditions were favorable for plant growth and no severe pest and diseases noticed during experimentation. The study involved twelve treatment combinations consisting of two factors viz., Varieties (three levels: $\mathrm{V}_{1^{-}}$BDN-711, $\mathrm{V}_{2^{-}}$BSMR-736, $\mathrm{V}_{3^{-}}$ BDN-716) and four irrigation levels (Rainfed (Control) ( $\left.\mathrm{I}_{1}\right), \quad$ Bud initiation $\left(\mathrm{I}_{2}\right), \quad$ Pod development $\left(\mathrm{I}_{3}\right), \quad$ Bud initiation and Pod development $\left(\mathrm{I}_{4}\right)$ were evaluated in factorial randomized block design with three replications. The Each experimental unit was repeated three times $5.40 \mathrm{~m} \times 5.0 \mathrm{~m}^{2}$ size in 
gross plot and in net plot $3.6 \times 4.2 \mathrm{~m}^{2}$. Sowing was completed on $9^{\text {nd }}$ July 2017 . The fertilizer dose of 25:50:00 NPK kg ha ${ }^{-1}$ was applied after sowing.

The shallow furrows were opened manually in each plot as per treatments and entire quantity of phosphorous $\left(50 \mathrm{~kg} \mathrm{P}_{2} \mathrm{O}_{2} / \mathrm{ha}\right)$ in the form of single super phosphate and $100 \%$ dose of nitrogen $(25 \mathrm{~kg} \mathrm{~N} / \mathrm{ha})$ in the form of urea were manually applied uniformly before sowing of pigeonpea crop in both the years. The package of recommended practices was adopted to maintain the crop.

\section{Results and Discussion}

\section{Effects on growth attributes}

\section{Varieties}

Plant height, number of functional leaves, mean number of branches and mean total dry matter plant $^{-1}$ were significantly influenced due to varieties. Amongst the varieties BDN716 recorded maximum plant height, number of functional leaves, mean number of branches and total dry matter plant $^{-1}$ at all growth stages, followed by BSMR-736 and BDN-711, respectively. The better performance of BDN716 may be attributed to its better vegetative growth over BSMR-736 and BDN-711, respectively (Table 1).

\section{Irrigation levels}

Irrigation stages significantly influenced all the growth attributes viz; plant height, number of functional leaves, mean number of branches and mean total dry matter plant ${ }^{-1}$ at 120,150 DAS and at harvest.

In general, significantly better performance of two irrigations at bud initiation + pod development was observed over rest of the irrigation stages and rainfed treatment, however, at 120 DAS it was at par with irrigation at pod development and irrigation at bud initiation. Number of functional leaves plant $^{-1}$ were on par for two irrigations at bud initiation + pod development and irrigation at pod development at all stages except at harvest. Comparable mean number of branches was observed due to irrigation at bud initiation + pod development, pod development and bud initiation, respectively.

Lowest value of growth attributes were observed with rainfed treatment. Significant effect of irrigation on growth attributes was also reported by Bhan and Khan (1979).

\section{Effect on yield attributes and yield}

\section{Varieties}

Various yield attributes viz., number of pods plant $^{-1}$, weight of pods plant ${ }^{-1}$, seed yield plant $^{-1}$ and seed index were significantly influenced due to three varieties under study, except number of seeds per pod which was not significantly influenced due to varieties.

BDN-716 recorded significantly maximum number of pods plant ${ }^{-1}$, weight of pod plant ${ }^{-1}$, seed yield plant ${ }^{-1}$ and seed index than BSMR736, respectively (Table 2 ).

\section{Irrigation levels}

Amongst irrigation stages, two irrigations at bud initiation + pod development produced significantly maximum number of pods plant ${ }^{-}$ 1 , weight of pods plant ${ }^{-1}$, seed yield plant ${ }^{-1}$ and seed index than rest of irrigation stages.

Number of seeds per pod was not significantly influenced due to irrigation stages. Superior performance of two irrigations at bud initiation + pod development over irrigation at bud initiation as well as irrigation at pod development and rainfed treatment might be 
attributed to better growth attributes and moisture availability during reproductive stage which might have helped in better source-sink relationship. Similar findings were reported by Pramod et al., (2010) (Table 3).

Effect on net monetary returns, gross monetary returns, benefit: cost ratio:

\section{Varieties}

BDN-716 recorded significantly maximum net monetary returns, gross monetary returns and benefit: cost ratio than BSMR-736.

It was comparable with BDN-711 in case of net monetary returns, gross monetary returns and benefit: cost ratio.

Improved economics under BDN-716 might be due to more seed yield compared to BSMR-736. Moreover, comparable GMR, NMR and B:C ratio was observed with BSMR-736 and BDN-711. Pramod et al., (2010) reported significant effect of variety on NMR and $\mathrm{B}: \mathrm{C}$ ratio.

\section{Irrigation levels}

Amongst irrigation stages, two irrigations at bud initiation + pod development noted significantly maximum net monetary returns, gross monetary returns and benefit: cost ratio than rest of the irrigation stages.

Significantly lowest GMR, NMR and B:C ratio was observed with rainfed treatment. Irrigation at pod development recorded significantly more GMR, NMR and $\mathrm{B}: \mathrm{C}$ ratio than irrigation at bud initiation and rainfed treatment, respectively.

These results indicated significance of soil moisture availability particularly under pod development stage which improved yield and ultimately NMR particularly when terminal

\section{Effect on water use efficiency}

Higher Irrigation water use efficiency was under BDN-716 which might be attributed to increased seed yield under variety BDN-716 (28.28 kg ha ${ }^{-1} \mathrm{~mm}^{-1}$ ) compared to BDN-711 (27.08 $\left.\mathrm{kg} \mathrm{ha}^{-1} \mathrm{~mm}^{-1}\right)$ and BSMR-736 (25.88 $\mathrm{kg} \mathrm{ha}^{-1} \mathrm{~mm}^{-1}$ ) as applied water was same (60 $\mathrm{mm}$ ) for all varieties under study.

This indicated significance of yield to improve IWUE of varieties to be grown. In case of irrigation stages higher irrigation water use efficiency was recorded with irrigation at pod development which might be due to less amount water applied under irrigation at pod development $(60 \mathrm{~mm})$ compared to irrigation at bud initiation + pod development $(120 \mathrm{~mm})$ and better seed yield.

Although irrigation at bud initiation + pod development recorded more seed yield (2076 $\mathrm{kg} \mathrm{ha}^{-1}$ ) it could not gave more irrigation water use efficiency due to more water applied and comparatively less increase in seed yield compared to additional irrigatin water applied under irrigation at pod development and irrigation at bud initiation.

Thus higher seed yield was masked by higher amount of water applied under two irrigations at bud initiation + pod development for improving water use efficiency in case of pigeon pea.

Similarly, better IWUE under irrigation at pod development over irrigation at bud initiation was due to equal irrigation water applied but comparatively better seed yield due to irrigation at pod development.

This indicated significance of moisture availability during pod development to improve IWUE of pigeonpea. Patel et al., (1993) also revealed lower WUE with increased application of irrigation water. 
Table.1 Growth and yield attributes of pigeonpea at harvest as influenced by various variety and drip irrigation

\begin{tabular}{|c|c|c|c|c|c|c|c|}
\hline Treatments & $\begin{array}{c}\text { Plant } \\
\text { height } \\
\text { (cm) }\end{array}$ & $\begin{array}{c}\text { Number of } \\
\text { branches } \\
\text { plant }^{-1}\end{array}$ & $\begin{array}{l}\text { Dry matter } \\
\text { production } \\
\left(\text { g plant }^{-1}\right)\end{array}$ & $\begin{array}{l}\text { Number of } \\
\text { pods plant }^{-1}\end{array}$ & $\begin{array}{l}\text { Weight of } \\
\text { pod plant }^{-1} \\
(\mathrm{~g})\end{array}$ & $\begin{array}{l}\text { Seed yield } \\
\text { plant }^{-1}(\mathrm{~g})\end{array}$ & $\begin{array}{l}\text { Number of } \\
\text { seed pod }\end{array}$ \\
\hline \multicolumn{8}{|l|}{ Varieties (03) } \\
\hline BDN-711 & 215.25 & 21.00 & 129.93 & 132 & 64 & 34 & 3.72 \\
\hline BSMR-736 & 221.33 & 22.20 & 131.21 & 130 & 59 & 33 & 3.69 \\
\hline BDN-716 & 227.67 & 22.64 & 137.42 & 143 & 69 & 36 & 3.78 \\
\hline $\mathrm{SE} \pm$ & 3.31 & 0.419 & 2.028 & 3.85 & 2.60 & 0.76 & 0.067 \\
\hline CD at $5 \%$ & 9.72 & 1.228 & 5.947 & 11.28 & 7.63 & 2.23 & NS \\
\hline \multicolumn{8}{|l|}{ Irrigations levels (04) } \\
\hline Rainfed (Control) & 215.11 & 20.83 & 128.35 & 109 & 49 & 27 & 3.58 \\
\hline Bud initiation & 220.56 & 21.80 & 129.67 & 124 & 62 & 31 & 3.69 \\
\hline Pod development & 223.44 & 22.28 & 134.06 & 137 & 66 & 36 & 3.77 \\
\hline Bud initiation and Pod development & 226.56 & 22.88 & 139.33 & 170 & 77 & 42 & 3.88 \\
\hline $\mathrm{SE} \pm$ & 3.83 & 0.484 & 2.342 & 4.44 & 3.00 & 0.88 & 0.077 \\
\hline CD at $5 \%$ & 11.22 & 1.418 & 6.867 & 13.03 & 8.81 & 2.57 & NS \\
\hline \multicolumn{8}{|l|}{ Interaction } \\
\hline $\mathrm{SE} \pm$ & 6.63 & 0.838 & 4.056 & 7.70 & 5.20 & 1.52 & 0.133 \\
\hline CD at $5 \%$ & NS & NS & NS & NS & NS & NS & NS \\
\hline General Mean & 221.42 & 21.95 & 132.85 & 134.94 & 63.55 & 34.16 & 3.73 \\
\hline
\end{tabular}


Table.2 Yield and economics of pigeonpea at harvest as influenced by various variety and irrigation levels

\begin{tabular}{|c|c|c|c|c|c|c|}
\hline \multirow[t]{2}{*}{ Treatments } & \multicolumn{2}{|c|}{ Yield (kg/ha) } & \multirow{2}{*}{$\begin{array}{c}\text { Cost of } \\
\text { cultivation } \\
(\mathrm{Rs} / \mathrm{ha})\end{array}$} & \multirow{2}{*}{$\begin{array}{c}\text { Gross } \\
\text { realization } \\
\text { (Rs/ha) }\end{array}$} & \multirow{2}{*}{$\begin{array}{c}\text { Net } \\
\text { realization } \\
\text { (Rs/ha) }\end{array}$} & \multirow[t]{2}{*}{ B:C ratio } \\
\hline & Grain & Stalk & & & & \\
\hline \multicolumn{7}{|l|}{ Varieties (03) } \\
\hline BDN-711 & 1625 & 2797 & 24890 & 72930.42 & 48224.08 & 2.92 \\
\hline BSMR-736 & 1553 & 2644 & 24890 & 69873.75 & 44984.08 & 2.79 \\
\hline BDN-716 & 1697 & 2892 & 24890 & 76350.00 & 51456.60 & 3.05 \\
\hline $\mathrm{SE} \pm$ & 36.41 & 66.23 & - & 1649.035 & 1638.260 & 0.066 \\
\hline CD at $5 \%$ & 106.78 & 194.22 & - & 4835.725 & 4804.126 & 0.193 \\
\hline \multicolumn{7}{|l|}{ Irrigations levels (04) } \\
\hline Rainfed (Control ) & 1218 & 2135 & 23690 & 54815.00 & 31119.55 & 2.31 \\
\hline Bud initiation & 1454 & 2510 & 24890 & 65165.56 & 40520.33 & 2.62 \\
\hline Pod development & 1751 & 2969 & 24890 & 78790.00 & 53900.33 & 3.16 \\
\hline Bud initiation and Pod development & 2076 & 3498 & 26090 & 93435.00 & 67345.33 & 3.58 \\
\hline $\mathrm{SE} \pm$ & 42.05 & 76.48 & - & 1904.142 & 1891.700 & 0.076 \\
\hline CD at $5 \%$ & 123.30 & 224.27 & - & 3583.814 & 5547.327 & 0.223 \\
\hline \multicolumn{7}{|l|}{ Interaction } \\
\hline $\mathrm{SE} \pm$ & 72.83 & 132.46 & - & 3298.071 & 3276.520 & 0.132 \\
\hline CD at $5 \%$ & NS & NS & - & NS & NS & NS \\
\hline General Mean & 1625 & 2778 & 24890 & 77051.39 & 48221.39 & 2.92 \\
\hline
\end{tabular}


Table.3 Irrigation water use efficiency studies as influenced by different variety and irrigation stages

\begin{tabular}{|c|c|c|c|c|}
\hline Treatments & Rainfall (mm) & water applied(mm) & $\begin{array}{c}\text { seed yield } \\
\left(\mathrm{kg} \mathrm{ha}^{-1}\right)\end{array}$ & $\begin{array}{c}\text { IWUE } \\
\left(\mathrm{kg} \mathrm{ha}^{-1} \mathrm{~mm}^{-1}\right)\end{array}$ \\
\hline \multicolumn{5}{|c|}{ Varieties } \\
\hline BDN-711 & 677.5 & 60 & 1625 & 27.08 \\
\hline BSMR-736 & 677.5 & 60 & 1553 & 25.88 \\
\hline BDN-716 & 677.5 & 60 & 1697 & 28.28 \\
\hline \multicolumn{5}{|l|}{ Irrigations stages } \\
\hline Rainfed (Control ) & 677.5 & - & 1218 & - \\
\hline Bud initiation & 677.5 & 60 & 1454 & 24.23 \\
\hline Pod development & 677.5 & 60 & 1751 & 29.18 \\
\hline $\begin{array}{l}\text { Bud initiation and Pod } \\
\text { development }\end{array}$ & 677.5 & 120 & 2076 & 17.3 \\
\hline Average & 677.5 & 60 & 1625 & 25.32 \\
\hline
\end{tabular}




\section{References}

Basu, T.K. and S.R. Bandyopadhyay. 2009. Productivity of rabi pigeon pea (cajanus cajan 1. Milsp.) As influenced by scheduling of irrigation. J. of crop and weed. 5(2): 90-91.

Bhan, S. and S. A., Khan.1979. Response of kharif crops to irrigation in light textured Alluvium of Uttar Pradesh. Indian J. Agron. 24 (4): 410-416.

Patel, J.R. and Z.G., Patel.1993. Effect of post-monsoon irrigation on yield and yield attributes of pigeonpea (Cajanus cajan). Indian J. Agron., 40: 220-22.

Pramod G.; B. T., Pujari; M. K., Basavaraja ; G., Vijaymahantesh and Venkate.2010. Yield, yield parameters and economics of pigeon pea [Cajanus cajan (L.) Millsp] as influenced by genotypes, planting geometry and protective irrigation, Int. J. of Agric. Sci., 6 (2) : 422-425.

\section{How to cite this article:}

Ghuge, G. V., K. T. Jadhav and Chavan, A. S. 2019. Response of Irrigation Scheduling on Yield Attributes, Productivity and Economics of Pigeonpea (Cajanus Cajan L.). Int.J.Curr.Microbiol.App.Sci. 8(10): 1644-1651. doi: https://doi.org/10.20546/ijcmas.2019.810.191 